The Review of Finance and Banking

print ISSN 2067-2713, online ISSN 2067-3825

Volume 11, Issue 2, Year 2019

http://dx.doi.org/10.24818/rfb.19.11.02.04, Pages 91-101

\title{
DOMESTIC INVESTMENT IN AFRICA: WHY THE EMERGING PUBLIC DEBT SPIRAL MATTERS?
}

\author{
FISAYO FAGBEMI* AND OLUFEMI SOLOMON OLATUNDE
}

\begin{abstract}
Given the prevailing view that public borrowing could be a springboard for boosting domestic investment levels in any economy, leveraging on multiple sources of finance to meet development financing needs is critical. In sub-Saharan Africa, however, the bleak investment landscape in the face of the emerging public debt spiral is worrying. Therefore, the study examines the effect of public debt on domestic investment in 33 SSA countries using Panel - Corrected Standard Error Estimation (PCSE) and one - step System GMM dynamic panel estimations over the period of 2000-2017. Empirical findings reveal that both debt (\% of GDP) and external debt stocks (\% of GNI) have a negative effect on domestic investment, implying that rising public debt tends to have adverse influence on investment levels across countries in SSA. Thus, the study posits that ensuring sustainable funding of developmental projects through the adoption of recent financial instruments that embed more resilience into the structure of public debt is central. Also, policy actors should introduce measures that could stimulate public investment efficiency, with borrowed funds effectively channeled towards investment-inducing projects such as infrastructure development for improved economic performance.
\end{abstract}

\section{INTRODUCTION}

In the face of evolving development challenges in Sub-Saharan Africa (SSA), concerns have emerged that rising levels of public debt have dire implication for sustainability. Given the size of finance or capacity constraints in Africa, leveraging on multiple sources of finance to meet development financing needs is critical, as such could play a crucial role in accelerating improved macroeconomic condition and investment. However, the structure and composition of both domestic and external debt matter in fiscal sustainability prospects (UNCTAD Economic Development in Africa Report, 2016). In most SSA countries, regulatory laxity, weak fiscal discipline, absence of clear policy direction, poor resource allocation and fiscal slippage account for outsized public debt build-up (Mustapha \& Prizzon, 2018; Kapoor et al., 2019). Despite the substantial debt relief accorded the region through the Heavily Indebted Poor Countries initiative (HIPC), debt accumulation is at the escalating stage. The increased fiscal deficits coupled with the highest debt ratios appear worrying given the pervasive infrastructure deficiencies. While the leading argument for high government borrowing is to deepen large capital investment projects, ill-considered policy and inefficient channeling approach often hamper its effectiveness (United Nations Economic Commission for Africa (UNECA), Economic Report on Africa, 2019). Hence, mainstreaming key institutional measures that bolster accountability, sound public finance management and strong incentive for sustainable investment are central

Received by the editors October 19, 2019. Accepted by the editors December 14, 2019.

Keywords: Public debt, Domestic investment, System GMM, Sub-Saharan Africa.

Fisayo Fagbemi, corresponding author*, Independent Researcher,Nigeria, ORCID iD: Fisayo Fagbemi https://orcid.org/0000-0002-5742-1514. E-mail: fisay4real@yahoo.com.

Olufemi Solomon Olatunde, Graduate Student, Department of Economics, Obafemi Awolowo University, Ile-Ife, Nigeria. E-mail: olufemi.olatunde@gmail.com.

This paper is in final form and no version of it will be submitted for publication elsewhere. 
for addressing the problematic funding instrument of governments' debt across countries in SSA.

Debt vulnerabilities and servicing challenges have been accentuating in recent years across African countries, as the number of countries with a debt ratio of more than $75 \%$ of GDP has increased twofold since 2011 (United Nations Economic Commission for Africa (UNECA), Economic Report on Africa, 2019). Accordingly, report indicates that public debt reached 59.1 $\%$ of GDP in 2017, and that many countries are plagued with high risk of debt distress. Given that public borrowing could be a springboard for boosting domestic investment levels, the bleak investment landscape in most SSA countries has generated concerns among researchers and analysts. Thus, questions on whether the state of domestic investment would be shaped by rising government debt levels are well enunciated in recent years in the region. Although anecdotal empirical evidence reveals that public debt has a vitiating effect on economic performance in SSA (Iyoha, 1999; Fosu, 1999; Senadza et al., 2018), its influence on domestic investment levels remains largely unaddressed. The prevailing conjecture is that a reduction of public debt, especially external debt, may lead to growth enhancement (Bonga et al., 2015). Essentially, research that could offer a substantive ground for the analysis on how public debt enhances or dampens the capacity of the economy to gain investment momentum requires due attention.

In theory, continued fiscal deficit expansion is a key driver of spiraling public debt in SSA. But the severity of a potential financial crisis can be eased by sound sovereign debt management, especially in poor macroeconomic policy settings. However, such better policy dimension cannot always preclude worse performance. In most cases, injudicious spending choices exacerbate unsustainable debt burdens. Hence, enhancing the rate of domestic investment requires the anchoring of improved capacity in robust macroeconomic policy measures and the efficient channeling of government borrowing into productive uses. Since irresponsible borrowing and lack of solid rules may have devastating economic consequences, creating fiscal space for muchneeded investment spending places further pressure on political leaders and public officials (Long \& Miller, 2017; Mustapha \& Prizzon, 2018). Attempts to address this issue appear to have underscored the need to exercise due diligence in their spending decisions. Nonetheless, these have been more complicated with the rise of public debt. This necessitates the requirement for an exclusive focus on SSA countries as whole. In light of limited systematic analysis and evidence directed towards ascertaining the role of public debt spiral in investment levels, a study is needed to offer concrete guidance on how governments can develop effective fiscal arrangement and better calibrate their approaches to policy adjustments for stimulating investment in the region.

Against this backdrop, the study's main objective is to examine the effect of public debt on domestic investment in SSA. Research of this nature would serve as a veritable tool to unveil the underlying institutional challenges and constraints facing policy actors responsible for maintaining sustainable fiscal trajectory, and in turn the strengthening of investment and development path. The rest of the paper is structured as follows; Section two deal with theoretical and empirical literature, followed by data description and methodological approach in section three. Section four contains empirical results and discussion. Finally, section five presents concluding remarks.

\section{Literature ReView}

2.1. Theoretical literature. The main expositions offer on debt-macroeconomic indicator nexus are based on certain theoretical propositions. In support of the linkage between public debt and investment, in the literature, many authors have proposed different theories. The following theories initiate and elucidate the influence of public debt on the economy: direct effect of debt hypothesis (DEDH), the dual-gap, debt overhang and liquidity constraint hypotheses. Regarding DEDH, it is stressed that irrespective of the inconsequential state of external debt in the savings and investment function, output growth can still be influenced through its effect on factor productivity and investment mix (Fosu, 1996). Although with a drag on investment, 
growth might be reduced, external debt could also impede the efficiency and effectiveness of the factors of production, and thus macroeconomic performance (Fosu, 1999). Moreover, Pattillo et al. (2004) state that high debt burden gives rise to uncertainty and hence induces investment towards short-term instruments against long-term investment. As such, due to higher uncertainty and risk that characterize long-term investment, projects with longer gestation periods would not be considered preferable by investors.

In another view, the dual-gap theory supported by Presbitero \& Panizza (2012) is centered on the postulation that investment is a function of saving. Accordingly, the theory emphasizes that external sources of capital to finance investment for economic development are required to complement the insufficient capacity of the domestic saving ${ }^{1}$. The central concern is to ascertain whether or not such external debt stimulates private investment in the indebted country, and to assess the extent to which such debt enhances domestic investment. Recognizing that in Africa, historically, the bulk of loans is usually provided by the external governments in form of long-term and on a concessional basis, Fosu (1996) hypothesizes that countries facing huge debt servicing repayments, compared with its available resources, may experience 'a relatively low productive investment mix'.

On the other hand, the effect of debt on investment levels is traced to the traditional hypotheses: debt overhang and liquidity constraint hypotheses. Based on debt overhang hypothesis (DOH), Krugman (1988); Froot (1989); Sachs (1989) assert that high levels of debt would cause an increase in the tax rate on expected returns to capital or future output and thereby engendering disincentive for saving and investment. Following neoclassical models, imposing taxes for the payment of interest on external debt could lead to a reduction in peoples' disposable income and in turn retards taxpayers' savings. In a nutshell, a large debt burden, indicative of excessive debt accumulation, would constrain investment and presumably productivity. The other hypothesis (liquidity constraint hypothesis $(\mathrm{LCH})$ ) posits that funds available for capital investment purposes in the economy are reduced by debt servicing requirement (Hoffman \& Reisen, 1991; Serieux \& Yiagadeseen, 2001). Thus, debt servicing inhibits the output, as it has a deleterious effect on investment under a binding liquidity constraint. Growing public debt could be inimical to domestic investment and macroeconomic performance (Pattillo et al., 2002).

2.2. Empirical evidence. The significant role of public finance has been identified in various ways by a number of authors. Recognizing that sustainable fiscal levels are the lifeblood of economic development, studies on the relationship between public sector policy and economic performance have gained considerable prominence. For instance, there has been a rising focus on the effect of public debt on macroeconomic indicators (such as economic growth, public investment and private investment) in the literature. However, the bulk of studies in this regard majorly centers on the relationship between public debt and economic growth (Moshi \& Kilindo, 1999; Checherita \& Rother, 2010; Apere, 2014; Kasidi \& Said (2013); Aristovnik et al., 2014; Kumar \& Woo, 2015), while few others direct efforts to public policy-private investment nexus (Blejer \& Khan, 1984; Vergara, 2004; Karago \& Ozdemir, 2006;) and fiscal policy-private investment linkage (Forni et al, 2009; Hermes \& Lensink, 2001; Alesina et al, 2002; Vergara, 2010). With respect to coverage, most of these studies are country-specific, and they do not take into account the recent development across SSA countries on how domestic investment could be affected by spiralling public debt in the region.

Following Moshi \& Kilindo (1999), a direct link is found between government policies and private investment from 1970 - 1992 in Tanzania. Also, although with a particular focus on growth effect, Kasidi \& Said (2013) debt service payment has an adverse influence on economic growth whereas external debt is found to have a positive effect in the country over the period of

\footnotetext{
${ }^{1}$ By equating the component of income and expenditure approach, the concept of national income accounting offer the basis for dual-gap analysis such that saving-investment gap would occur, if the domestic saving fall shorts of economic growth target (Balago, 2014).
} 
1970-2010 with OLS application. Using ARDL model, Jilenga \& Xu (2016) examine the impact of external debt and foreign direct investment (FDI) on economic growth in Tanzania. The authors support the previous conclusion (1971-2011). In a more recent study, Mabula \& Mutasa (2019) stress that, in the long-run as well in the short-run, the combined effect of domestic and external debt on private investment is found to be statistically significant. However, based on Southern African Development Community (SADC) countries, Sichula (2012), using a combination of overhang model and financial model in a study on "Debt Overhang and Economic Growth in HIPC Countries", posits that there is no direct relationship between debt service and private investment. The author establishes that debt overhang remains a paradox.

In the context of developed countries, using a panel of OECD countries, Alesina et al (2002) investigate the effects of fiscal policy on investment. Compared with the effect of various types of taxes on business investment, the authors argue that public spending has a significantly greater and substantial adverse effect on business investment. Analoguosly, Arin (2004); Balls (2005) buttress this assertion that rather than changes in tax, changes in public expenditure have a greater influence on private investment. However, Soli et al. (2008) reveal that changes in tax on domestic goods and services, income and property taxes and international trade taxes matter for private capital investment. In another study, with a focus on $14 \mathrm{EU}$ countries, Marratin \& Salotti (2010) show that expenditure shocks have a positive effect on private investment. Nonetheless, in the study of Traum \& Yang (2010), a limited relationship is found among public debt, real interest rate and private investment. They further elucidate that, although depending on the cause of the debt (\% of GDP), in the short run, public debt can either crowd in or crowd out private investment. With a more contrary view, Sanchez-Juarez \& GarciaAlmada (2016) applying dynamic models of panel data and Generalized Method of Moments (GMM) on 32 states in Mexico between 1993 and 2012, establish that public debt positively correlates with public investment, which in turn stimulates economic growth.

Focusing on Nigeria, Isah (2012) claims that fiscal policy, in terms of expenditure and budget deficits, crowds out private investment in the country. Similarly, with respect to Ghana, NaaIdar et al. (2012) corroborate the assertion that fiscal policy has a negative and significant impact on private investment. Furthermore, Atoyebi et al (2012); Ezeabasili \& Nwakoby (2013); Kibet (2013) confirm the repressive effect of both fiscal deficit and public debt on private investment in Nigeria. Regarding SSA, Hoffman and Resen (1991); Savvides (1992) elucidate that public debt has a negative influence on domestic savings and investment. In a more recent study, Omojolaibi et al. (2016), applying Fixed Effect model, confirm an insignificant crowdout effect of recurrent expenditure and external debt on private investment in 5 West African countries over the period of 1993 to 2014. By and large, major studies on SSA concentrate on the relationship between external debt and growth, and they commonly indicate that there exists a negative association between external debt and economic growth in the region (Fosu, 1996; 1999; Iyoha, 1999; Senadza et al., 2018). Hence, it is pertinent to unravel public debt-investment nexus in SSA. The use of one-system Generalized Method of Moments (GMM) estimation, which could

control for country-groupings based on per capita income, would provide a sufficient empirical basis for emerging evidence and building resilience into fiscal policy framework.

\section{Data And methodology}

3.0.1. Data. This study employs panel data on 33 SSA countries between 2000 and 2017. The choice for the time frame is based on data availability and in view of significant efforts made in recent periods towards stimulating domestic investment levels and economic development through restructuring debt deals. Besides, it encompasses the year (2012) when public debt began to escalate across countries sequel to the debt relief initiative (HIPC). In the study, gross capital formation is used as an indicator of domestic investment $(I)$, which consists of outlays on additions to the fixed assets of the economy plus net changes in the level of inventories. Accordingly, debt (\% of GDP) and external debt stocks (\% of GNI) are employed as a measure of public debt (PUD). Debt (\% of GDP) represents the ratio of a country's public debt to 
its gross domestic product (GDP), whereas external debt stocks (\% of GNI) is debt owed to nonresidents repayable in currency, goods, or services. In relation to Jorgensen (1967); Malik (2013); Soli et al (2008), the following variables can also shape the investment trajectory of any economy: GDP per capita (GDP), domestic credit to private sector (\% of GDP) (PCREDIT) and Inflation $(I N F)$. These variables are included as control variables. GDP is based on constant 2010 US\$. INF, which represents the inflation rate, is based on consumer price index (annual $\%$ ). On the other hand, PCREDIT is defined as the financial resources provided to the private sector by financial corporations, such as through loans, purchases of non-equity securities, and trade credits and other accounts receivable that establish a claim for repayment. Data are sourced from World Bank's World Development Indicators and IMF Database (2018).

3.1. Methodology. Following the flexible accelerator model (Asante, 2000; Agidew, 2014), we derive an investment function of the form:

$$
I_{i t}=\lambda\left(K^{*}{ }_{i t}-K_{i t-1}\right) \quad i=1, \ldots, N \quad t=1, \ldots, T
$$

Based on the hypothesis, $\lambda$ is the gap in the existing stock of capital such that the difference between the previous year $\left(K_{i t-1}\right)$ and the desired stock of capital $\left(K_{i t}^{*}\right)$. In this case, firm's investment $\left(I_{i t}\right)$ seeks to fill this gap. The basic assumption is that; the larger the gap, the greater the rate of firm's investment. Within the model's framework; output, domestic and external financing and other variables can be incorporated as determinants of desired capital stock $\left(K^{*}{ }_{i t}\right)$. Hence,

$$
K^{*}{ }_{i t}=f\left(P U D_{i t}, X_{i t}\right)
$$

PUD represents public debt while $X$ is the set of control variables (GDP, PCREDIT, and $I N F$ )

The net investment $\left(N I_{i t}\right)$ is stated as:

$$
N I_{i t}=\Delta K^{*}{ }_{i t}
$$

Since replacement investment is ignored, we assume that:

$$
I_{i t}=N I_{i t}
$$

Substituting Eq. (3) into (4), we have:

$$
I_{i t}=\Delta K^{*}{ }_{i t}
$$

Eq. (5) is now augmented with public debt and the control variables in the form;

$$
I_{i t}=\Delta f\left(P U D_{i t}, X_{i t}\right)
$$

Eq. (6) can be transformed into basic econometric model as:

$$
I_{i t}=\alpha_{0}+\alpha_{1} P U D_{i t}+\alpha_{2} X_{i t}+\vartheta_{i t}
$$

Where $\vartheta$ is the error term. $\alpha_{0}$ represents the constant while $\alpha_{1} \& \alpha_{2}$ are the unknown parameters.

Given that investment indicators in their diverse forms of measurement are dynamic in nature, and as some of the explanatory variables are likely to jointly determine investment levels, endogeneity of the explanatory variables ought to be controlled for. Taking these aspects into consideration, the appropriate estimation technique to employ is one-step system Generalized Method of Moments (GMM) estimator for dynamic panel data model developed by Arellano \& Bover (1995); Blundell \& Bond (1998). This estimator deals with country-specific effects and potential endogeneity of the independent variables. The control for endogeneity is achieved by using instruments based on lagged values of the explanatory variables. A model containing 
lagged dependent variables among the regressors must represent the dynamic nature of the domestic investment. In the analysis, one lag period of the dependent variable is adopted:

$$
I_{i t}=\partial I_{i t-1}+\alpha_{1} P U D_{i t}+\alpha_{2} X_{i t}+\vartheta_{i t}
$$

Where $\partial$ is a scalar, while assuming that $\vartheta$ follows a one-way error component model:

$$
\vartheta_{i t}=\mu_{i}+\nu_{i t}
$$

Where $\mu_{i} \sim \operatorname{IID}\left(0, \sigma^{2}{ }_{\mu}\right) \quad \& \quad \nu_{i t} \sim \operatorname{IID}\left(0, \sigma^{2}{ }_{\nu}\right)$ are independent of each other and among themselves. Since $I_{i t}$ is a function of $\mu_{i}, I_{i t-1}$ is also a function of $\mu_{i}$. Therefore, $I_{i t-1}$ is correlated with error term. In this case, ordinary least square estimator is rendered biased and inconsistent. In relation to system GMM, the first difference transformation wipes out the individual effect. This approach works in this way: take first differences of Eq. (8), and generalize to an equation (model) comprising lagged dependent as regressor, thus form:

$$
\Delta I_{i t}=\partial \Delta I_{i t-1}+\alpha_{1} \Delta P U D_{i t}+\Delta \alpha_{2} X_{i t}+\Delta \vartheta_{i t}
$$

Where $\Delta I_{i t}=\Delta I_{i t}-I_{i t-1}$. First differencing eliminates country-specific effects, although by construction, it leads to correlation between the differenced lagged investment variable and differenced error term. As a consequence, lagged levels of the explanatory variables, with the inclusion of lagged dependent variable as instruments, are adopted in the estimation. This estimation technique (System GMM) will be consistent and efficient if the lagged levels of independent variables in the model are valid instruments for differenced independent variables. Furthermore, for the robustness of the estimates, Panel-Corrected Standard Error' (PCSE) Estimation is employed. These methods are appropriate for this study, as time periods $(\mathrm{T})$ is less than the number of Cross-section (N). Another reason for the appropriateness of PCSE is that when disturbances indicate both serial and contemporaneous correlation, this technique gives better and efficient estimates (Parks, 1967).

3.2. Results and Discussion. With summary statistics in Table 1, the essential features of the variables are being displayed. As results indicated, GDP has the highest overall mean value followed by debt (\% of GDP), external debt stocks, gross capital formation, private credit and inflation. Given the overall standard deviation, it could be observed that there is a $64.90 \%$ and $116.25 \%$ range of fluctuations in debt (\% of GDP) and external debt stocks respectively, whereas domestic investment (gross capital formation) fluctuated within the range of $9.16 \%$ over the period of 2000-2017 in SSA. But for between and within categories, $44.47 \%$ and $48.25 \%$ are for public debt respectively, $77.03 \%$ and $88.03 \%$ are for external debt stock, and for gross capital formation, between and within values are given as $6.67 \%$ and $6.37 \%$ respectively. Regarding pairwise correlation shown in Table 2, although the parameters are significant, both debt (\% of GDP) and external debt stock inversely correlated with gross capital formation, underscoring that these two fiscal indicators may vitiate domestic investment and development trajectory in the region. However, with exemption of inflation, GDP and private credit as control variables maintain direct association with the investment indicator, underlining that the improvement of these macroeconomic measures may lead to accelerated capital formation across countries.

In the study, two models are employed. Since levels of public debt are determined by both internal and external borrowing, debt (\% of GDP) and external debt stocks are the indicators used to measure the effect of public debt on domestic investment. Accordingly, given that these fiscal indicators are highly correlated (see table 2), they cannot be incorporated into the model concurrently. 


\begin{tabular}{|c|c|c|c|c|c|c|}
\hline & \multirow{2}{*}{$\begin{array}{c}\text { Investment indicator } \\
\text { Gross capital }\end{array}$} & \multicolumn{2}{|c|}{ Fiscal indicator } & \multicolumn{3}{|c|}{ Macroeconomic indicator } \\
\hline & & Debt & External & GDP & Private & Inflation \\
\hline & formation & $(\%$ of $\mathrm{GDP})$ & debt stocks & & credit & \\
\hline \multicolumn{7}{|l|}{ Mean } \\
\hline Overall & 22.07 & 68.62 & 67.10 & 1715.21 & 19.23 & 9.49 \\
\hline \multicolumn{7}{|c|}{ Standard deviation } \\
\hline Overall & 9.16 & 64.90 & 116.25 & 2328.08 & 26.20 & 31.32 \\
\hline Between & 6.67 & 44.47 & 77.03 & 2332.92 & 25.68 & 13.33 \\
\hline Within & 6.37 & 48.25 & 88.03 & 365.34 & 6.02 & 28.43 \\
\hline \multicolumn{7}{|l|}{ Minimum } \\
\hline Overall & 1.10 & 6.44 & 3.90 & 213.41 & 0.40 & -7.4 \\
\hline Between & 9.83 & 13.24 & 10.73 & 227.92 & 3.48 & 1.48 \\
\hline Within & -4.15 & -140.03 & -376.33 & -319.88 & -11.07 & -54.42 \\
\hline \multicolumn{7}{|l|}{ Maximum } \\
\hline Overall & 73.78 & 523.38 & 1380.78 & 10199.91 & 160.13 & 550 \\
\hline Between & 40.82 & 235.64 & 475.01 & 9389.49 & 141.03 & 64.81 \\
\hline Within & 69.45 & 356.36 & 972.87 & 4319.80 & 43.45 & 494.68 \\
\hline \multicolumn{7}{|c|}{ Observation } \\
\hline $\mathrm{N}$ & 588 & 522 & 594 & 594 & 584 & 594 \\
\hline $\mathrm{N}$ & 33 & 33 & 33 & 33 & 33 & 33 \\
\hline $\mathrm{T}$ & 17.82 & 15.82 & 18 & 18 & 17.70 & 18 \\
\hline
\end{tabular}

Thus, model (1) represents the inclusion of the debt (\% of GDP), while model (2) two accounts for the use of external debt stocks as explanatory variables. As stated previously, Panel - Corrected Standard Error Estimation (PCSE) ensures that a model has efficient and unbiased estimates even when there is possible serial and contemporaneous correlation.

\begin{tabular}{|c|c|c|c|c|c|c|}
\hline \multicolumn{7}{|c|}{ Table 2: Pairwise correlation coefficient } \\
\hline & Gross capital & Debt & External & GDP & Private & Inflation \\
\hline & formation & $(\%$ of GDP $)$ & debt stocks & & credit & \\
\hline Gross capital formation & 1.00 & & & & & \\
\hline Debt (\% of GDP) & $-0.24^{*}$ & 1.00 & & & & \\
\hline External debt stock & $-0.10^{*}$ & $0.85^{*}$ & 1.00 & & & \\
\hline GDP & $0.16^{*}$ & $-0.21^{*}$ & $-0.11^{*}$ & 1.00 & & \\
\hline Private credit & 0.02 & $-0.20^{*}$ & $-0.13^{*}$ & $0.59^{*}$ & 1.00 & \\
\hline Inflation & -0.02 & 0.09 & 0.04 & -0.05 & -0.07 & 1.00 \\
\hline \multicolumn{7}{|c|}{$*$ represents correlation coefficients significant at the $5 \%$ level or better } \\
\hline
\end{tabular}

This approach, therefore, performs much better than panel regression analysis given the susceptibility of OLS, random and fixed effect estimations to potential endogeneity and simultaneity issue commonly associated with explanatory variables which could bias and make their estimated outcomes inconsistent (Deaton, 1995). Thus, for the robustness of the estimates, in addition to one - step System GMM dynamic panel estimations, PCSE is applied in both models. It is often required that for System GMM to be efficient and consistent some certain conditions need to be met. Hence, a set of diagnostic tests are conducted on the specifications. One of the tests (Arrelano-Bond test for the second order serial correlation) indicates that there is an absence of second order serial correlation in the models. Moreover, in all, the number of instruments is less than the number of observations. In relation to the test of over-identifying restrictions (Sargan test), the instruments are valid. Also, Pesaran CD (serial dependence) test shows that there is no serial correlation. In view of satisfied conditions, these tests buttress the rule of thumb and the veracity of the results is confirmed. 
In the two techniques, estimated results, in table 3 , reveal that both debt (\% of GDP) and external debt stocks (\% of GNI) have an adverse effect on domestic investment (gross capital formation), but show statistically negligible relationship under System GMM estimation. The similarity of outcomes substantiates the tenability of the estimates. The findings suggest that effectiveness of public borrowing in stimulating domestic investment is hindered by inadequate monitoring, coordination and poor channeling across countries in sub-Saharan Africa. For instance, institutional mechanisms underpinning transparency and accountability and effective fiscal management are pervasively shallow and weak in the region. Borrowed funds are often stashed away by corrupt public officials. Thus, public debt remains the burden of responsibility to governments, especially with respect to external debt. The evidence for the negative effect of domestic and external debt are strongly linked to poor governance. The depth of domestic investment has no systematic relationship with public debt in SSA (Bonga et al., 2015; Mustapha \& Prizzon, 2018; United Nations Economic Commission for Africa (UNECA), Economic Report on Africa, 2019). As a consequence, public debt undermines the growth of investment, thereby heightening development pressures. In terms of control variables, GDP and domestic credit to private sector (\% of GDP) positively associate with the gross capital formation (investment), although only GDP is statistically significant. This implies that improved economic performance and deepening financial sector could enhance capital formation across economies. These findings underscore the substantial linkage between macroeconomic performance and domestic investment levels. In this regard, the empirical assertion marries up with the evidence provided by Fosu (1999); Kumar \& Woo (2015); Senadza et al. (2018). While inflation is statistically relevant in explaining the extent to which investment path accelerates, it has weak and minimal influence on gross capital formation.

\begin{tabular}{|c|c|c|c|c|}
\hline \multirow[t]{2}{*}{ Gross capital formation - $\log$} & \multicolumn{2}{|c|}{ Panel - corrected (PCSE) } & \multicolumn{2}{|c|}{ System GMM estimation } \\
\hline & Model 1 & Model 2 & Model 1 & Model 2 \\
\hline \multirow[t]{2}{*}{ Gross capital formation (lag) - $\log$} & & & $0.71 * * *$ & $0.75^{* * *}$ \\
\hline & & & {$[9.37]$} & {$[12.20]$} \\
\hline \multirow{2}{*}{ Debt $(\%$ of GDP $)-\log$} & $-0.11 * * *$ & & -0.03 & \\
\hline & {$[-3.32]$} & & {$[-0.81]$} & \\
\hline \multirow[t]{2}{*}{ External debt stocks - log } & & $-0.07 * *$ & & -0.01 \\
\hline & & {$[-2.69]$} & & {$[-0.26]$} \\
\hline \multirow{2}{*}{ GDP - $\log$} & $0.14^{* * *}$ & $0.14^{* * *}$ & $0.13^{* *}$ & $0.07^{*}$ \\
\hline & {$[3.33]$} & {$[3.64]$} & {$[2.58]$} & {$[1.60]$} \\
\hline \multirow[t]{2}{*}{ Private credit $-\log$} & 0.02 & 0.02 & 0.01 & 0.03 \\
\hline & {$[0.39]$} & {$[0.48]$} & {$[0.34]$} & {$[0.88]$} \\
\hline \multirow[t]{2}{*}{ Inflation } & 0.001 & 0.001 & $0.01 * *$ & $0.01^{* *}$ \\
\hline & {$[1.27]$} & {$[1.22]$} & {$[2.15]$} & {$[2.73]$} \\
\hline \multirow[t]{2}{*}{ Constant } & $2.37 * * *$ & $2.21 * * *$ & 0.04 & 0.22 \\
\hline & {$[6.52]$} & {$[6.90]$} & {$[0.11]$} & {$[0.71]$} \\
\hline $\mathrm{R} 2$ & 0.57 & 0.52 & & \\
\hline Observations & 514 & 580 & 484 & 548 \\
\hline No. of countries & 33 & 33 & 33 & 33 \\
\hline No. of instruments & & & 57 & 65 \\
\hline Pesaran CD (P-value) & 0.28 & 0.41 & & \\
\hline$A$ - Bond AR(1) test p-value & & & $-4.81(0.00)$ & $-5.18(0.00)$ \\
\hline $\mathrm{A}$ - Bond AR(1) test p-value & & & $-1.01(0.31)$ & $-1.06(0.29)$ \\
\hline Sargan test & & & $49.21(0.51)$ & $51.18(0.13)$ \\
\hline \multicolumn{5}{|c|}{ Figures in parentheses are t-values. $\left(*^{* *}\right),\left(*^{*}\right) \&(*)$ indicate significance at $1 \%, 5 \%$ and $10 \%$ respectively. } \\
\hline \multicolumn{5}{|c|}{ Model (1) represents the inclusion of debt (\% of GDP) as the independent variable, } \\
\hline whereas shows the inc & sion of & debt sto & the indep & iable. \\
\hline
\end{tabular}


In sum, the adverse relationship between public debt and the level of investment in SSA could be attributed to the growing incidence of governance challenges in the region. Results lend credence to the assertion that a large debt burden could constrain investment and presumably productivity (Krugman (1988); Froot (1989). However, it could be argued that these findings might only reflect the average fiscal behavior of SSA rather than the fiscal approach of emerging markets and frontier economies. In the context of the inimical role of public debt in domestic investment activities, the ability of the government is constrained in using the borrowed funds for investment expansion. Due to excessive spending, feeble regulatory framework and terrible habit formation patterns, rising fiscal deficits could be deleterious to the region's economies. In the face of ample access to domestic funding and higher gross debt inflows, governments may adopt unsustainable fiscal plans (Kaminsky, Reinhart, \& Vegh, 2005). Overall, the econometric evidence signals a considerable heightening of low investment levels through growing public debt. In general, the study's conclusion is based on the System GMM estimations, given its efficiency, consistency and reliability.

\section{Concluding Remarks}

With the common understanding that public borrowing could be a springboard for boosting domestic investment levels, the bleak investment landscape in most SSA countries coupled with the public debt spiral have generated concerns among economists. In line with this severe development, the study examines the effect of public debt on domestic investment in 33 SSA countries using Corrected Standard Error Estimation (PCSE) and one - step System GMM dynamic panel estimations over the period of 2000-2017. These countries include: Angola, Benin, Botswana, Burkina Faso, Burundi, Cameroon, Central African Republic, Chad, Comoros, Congo, Congo DR, Cote d'lvoire, Gabon, Gambia, Ghana, Guinea, Guinea Bissau, Kenya, Liberia, Malawi, Mali, Mauritania, Mauritius, Mozambique, Niger, Nigeria, Rwanda, Senegal, Sierra Leone, South Africa, Tanzania, Togo and Uganda. In light of the main objective, two fiscal indicators are employed (debt (\% of GDP) and external debt stock (\% of GNI), with their respective effects analyzed accordingly.

The findings inferred from the analysis suggest that rising public debt tends to have a vitiating effect on investment levels across countries in the region. The thirty-three countries under focus do not get their investments improved through borrowed funds. Assessing the degree of financial resource misallocation and diversion in an environment with multiple ill-considered policies and fiscal slippage, evidence suggests that unsustainable debt burdens, coupled with under-investment are inevitable in SSA countries, and that the effect is compounded by behavioral distortions in the public sector. Thus, it is emphasized that effectiveness of public borrowing in enhancing domestic investment is undermined by inadequate monitoring, coordination and poor channeling. Furthermore, shallow institutional mechanisms underpinning transparency and accountability and effective fiscal management are found to be responsible for the huge investment and development gaps in Africa. However, the study supports the view that improved macroeconomic performance and financial deepening could engender higher levels of domestic investment, although with the espousal of sound public finance management and strong incentives for sustainable investment. Hence, it is posited that ensuring sustainable funding of developmental projects through the adoption of recent financial instruments that embed more resilience into the structure of public debt is central.

In general, the study critically reveals reasons for the failure of governments in most African countries to effectively leverage public borrowing for better performance and investment-enhancing approach. It is further asserted that the pervasive infrastructure deficiencies (low investments in critical infrastructure) across countries would remain unabated if the institutional framework is not strengthened in SSA, as the region is well known for poor governance and lack of accountability and transparency in the public sector. By implication, policy actors should 
introduce measures that could stimulate public investment efficiency with borrowed funds effectively channeled towards investment-inducing projects such as infrastructure development for improved economic performance.

\section{REFERENCES}

[1] Agidew, E.T. (2014). An Investigation of Macroeconomic Determinants of Domestic Private Investment Evidence from East Africa.

[2] Alesina, A., Ardagna, R. P., Perotti, R. \& Schiantarelli, F. (2002). Fiscal Policy, Profits, and Investment. The American Economic Review, 92, 571-589.

[3] Apere, T.O. (2014). The Impact of Public Debt on Private Investment in Nigeria: Evidence from a Nonlinear Model. International Journal of Research in Social Sciences, 4(2), pp.130-138.

[4] Arellano, M. \& Bover, O. (1995). Another Look at the Instrumental Variable Estimation of ErrorComponents Models. Journal of Econometrics, 68, pp.29-51.

[5] Arin, K. (2004). Fiscal Policy, Private Investment-7 and Countries. Retrieved from http://papers.ssrn.com/sol3/papers.cfm? abstractid $=438785$.

[6] Aristovnik, A., Mencinger, J. \& Verbic, M. (2014). The Impact of Growing Public Debt on Economic Growth in European Union. Munich Personal RePec Archive, Paper No., (53243).

[7] Asante, Y. (2000). Determinants of Private Investment Behaviour in Ghana. African Consortium Reserarch Paper (Nairobi): Kenya.

[8] Atoyebi, K. O., Adekunjo, F. O., Kadiri, K. I. \& Falana, A. A. (2012). The Determinants of Domestic Private Investment in Nigeria. Journal of Humanities and Social Science (JHSS), 2(6), 46-54.

[9] Balago, G.S. (2014). An Empirical Analysis of the Relationship between Government External Borrowings and Economic Growth in Nigeria. , 3(4), pp.235-243.

[10] Balls, A. (2005). How Government Spending Slows Growth. Retrieved 2014, from www.nber.org: www.nber.org/digest/jan00/w7207.html.

[11] Blejer, M., \& Khan, M. S. (1984). Government Policy and Private Investment in Developing Countries. IMF Staff Paper, 31 (2), 379-403.

[12] Blundell, R. \& Bond, S. (1998). Initial Conditions and Moment Restrictions in Dynamic Panel Data Models. Journal of Economics, (87): 115-43.

[13] Bonga, W. G., Chirowa, F., \& Nyamapfeni, N. (2015). Growth-debt nexus: An examination of public debt levels and debt crisis in Zimbabwe. Journal of Economics and Finance, 6(2), 09-14.

[14] Checherita, C. \& Rother, P. (2010). The impact of high and growing government debt on economic growth: an empirical investigation for the euro area: Working Paper Series., No. 1237, Publication by European Central Bank.

[15] Ezeabasili, V. N., \& Nwakoby, N. C. (2013). Fiscal Deficits and Private Investment: Econometric Evidence from Nigeria. International journal of Innovative Research in Management, 3(2), 1-18.

[16] Forni, L., Monteforte, L., \& Sessa, L. (2009). The General Equilibrium Effects of Fiscal Policy: Estimates for the Euro Area. Journal of Public Economics, 93(3-4), 559-585.

[17] Fosu, A. K. (1996). The impact of external debt on economic growth in sub-Saharan Africa. Journal of Economic Development, 21(1): 93-117.

[18] Fosu, A. K. (1999). The external debt burden and economic growth in the 1980s: Evidence from SubSaharan Africa. Canadian Journal of Development Studies, 20 (2): 307-318.

[19] Froot, K. (1989). Buybacks, exibonds and the optimality of debt and liquidity relief. International economic review, 30: 49-70.

[20] Hermes, N., \& Lensink, R. (2001). Fiscal Policy and Private Investment in Less Developed Countries. World Institute for Development Economics research, 32.

[21] Hoffman, B. \& Reisen, H. (1991). Some Evidence on Debt-Related Determinants on Investment and Consumption in Heavily Indebted Countries. Welt Wirschafiliches Archive, 127(2): 280-297.

[22] Isah, I. P. (2012). Deficit Financing and its Implication on Private Sector Investment: The Nigerian. Arabian Journal of Business and Management Review, 1(9).

[23] Iyoha, M. A. (1999). External Debt and Economic Growth in Sub-Saharan African Countries: An Econometric Study. AERC Research Paper 90, Nairobi Kenya.

[24] Jilenga, M.T. \& Xu, H. (2016). The Impact of External Debt and Foreign Direct Investment on Economic Growth: Empirical Evidence from Tanzania., 7(2), pp.154-162.

[25] Jorgensen, D. (1967). The Theory of Investment Behaviors, in Determinants of Investment. National Bureau of Economic Research, 129-155.

[26] Kaminsky, G. L., Reinhart, C.M. \& Vegh, C.A. (2005). When It Rains, It Pours: Procyclical Capital Flows and Macroeconomic Policies. In NBER Macroeconomics Annual 2004, vol. 19, edited by M. Gertler and K. Rogoff. Cambridge, MA: National Bureau of Economic Research.

[27] Kapoor, K., Kararach, G., Odour, J., Odero, W., Sennoga, E. Coulibaly, B., Nakata, R. (2019). Cooperation with Africa: Fiscal and debt sustainability in Africa. G20, 2019, Japan. 
[28] Karago, E., \& Ozdemir, K. (2006). Government Expenditure and Private Investment: Evidence from Turkey. The Middle East Business and Economic Review, 18(2), 33-38.

[29] Kasidi, F. \& Said, A.M. (2013). Impact of External Debt on Economic Growth: A Case Study of Tanzania. , 3(4), pp.59-82.

[30] Kibet, K. S. (2013). Effect of budget deficit and corruption on private investment in developing countries: A panel data analysis. African Journal of Business Management, 7(27), 2720-2732.

[31] Krugman, P. (1988). Financing versus forgiving a debt overhang. NBER Working Paper 2486. www.nber.org/papers (accessed 23 May 2016).

[32] Kumar, M.S. \& Woo, J. (2015). Public Debt and Growth. Economica, 2015(82), pp.705-739.

[33] Long, C. \& Miller, M. (2017). Taxation and the Sustainable Development Goals: do good things come to those who tax more? ODI Briefing Note, London: Overseas Development Institute.

[34] Mabula, S. \& Mutasa, F. (2019). The Effect of Public Debt on Private Investment in Tanzania. African Journal of Economic Review, VII (I): 109-135.

[35] Malik, A. (2013). Private Investment and Fiscal Policy in Pakistan. Journal of Economic Development, 38(1), 89-91.

[36] Marattin, L. \& Salotti, S. (2010). On the Usefulness of Government Spending in the EU area. MPRA Paper No. 24906.

[37] Moshi, H.P.B. \& Kilindo, A.A.L. (1999). The Impact of Government Policy on Macroeconomic Variables: A Case Study of Private Investment in Tanzania. African Economic Reserch Consortium, Paper No 8(1999), p.Nairobi.

[38] Mustapha, S. \& Prizzon, A. (2018). Africa's rising debt: How to avoid a new crisis. ODI Briefing Note, London: Overseas Development Institute,

[39] Naa-Idar, F., Ayentimi, D. T. \& Frimpong, M. J. (2012). A Time Series Analysis of Determinants of Private Investment in Ghana (1960-2010). Journal of Economics and Sustainable Development, 3(12), 23-33.

[40] Omojolaibi1, J.A. Tochi-Nze P. Okenesi, T.P. \& Mesagan E.P. (2016). Fiscal Policy and Private Investment in Selected West African Countries. CBN Journal of Applied Statistics, 7(1): 277-309.

[41] Parks, R. (1967). Efficient Estimation of a System of Regression Equations when Disturbances are both serially and Contemporaneously Correlated. Journal of the American Statistical Association, 62, 500-9.

[42] Pattillo, C., Poirson H. \& Ricci, L. (2002). External Debt and Growth. IMF Working Paper 02/69, 1-47. http://www.imf.org/pubs/2002 (Accessed 20 May 2016).

[43] Pattillo, C., Poirson, H., Ricci, L., Kraay, A., \& Rigobon, R. (2004). Through what channels does external debt affect growth? The Brooking Trade Forum, 229-277. http://www.grips.ac.jp/docu01/paper06 (Accessed 23May 2016).

[44] Presbitero, A.F. \& Panizza, U. (2012). Public Debt and Economic Growth: Is There a Causal Effect? POLIS Online Working Papers. ISSN 2038-7296.

[45] Sachs, J. (1989). The debt overhang of developing countries, in G.calvo, R. Findlay, P. Kouri and J. Macedo (eds.), debt, stabilization and development. Essay in memory of Carlos Diaz - Alejardo, Oxford: Basic Blackwell, 80-102.

[46] Sanchez-Juarez, I. \& Garcia-Almada, R. (2016). Public Debt, public investment and economic growth in Mexico, International Journal of Financial Studies, 2016, 4 (6); doi: 10.3390/ijfs4020006.

[47] Savvides, A. (1992). Investment slowdown in developing countries during the 1980s: Debt overhang or foreign capital inflows? Kyklos, 45(3): 363-378.

[48] Senadza, B., Fiagbe, A. K. \& Quartey, P. (2018). The effect of external debt on economic growth in SubSaharan Africa. International Journal of Business and Economic Sciences Applied Research (IJBESAR), ISSN 2408-0101, Eastern Macedonia and Thrace Institute of Technology, Kavala, Vol. 11, Iss. 1, pp. 61-69, http://dx.doi.org/10.25103/ijbesar.111.07.

[49] Serieux, J. \& Yiagadeesen, S. (2001). The debt service burden and growth: Evidence from low income countries. The North-South Institute, Ottawa.http://www.researchgate.net/publication (Accessed20 May 2016).

[50] Sichula, M. (2012). Overhang and Economic Growth in HIPC Countries: The Case of Southern African Development Community (SADC). International Journal of Economics and Finance, 4(10), pp.82-92.

[51] Soli, V., Harvey, S. K. \& Hagan, E. (2008). Fiscal Policy, Private Investment and Economic Growth: The Case of Ghana. Studies in Economics and Finance, 25(2), 112-130.

[52] Traum, N. \& Yang, S. (2010). Does Government Debt Crowd Out Investment? A Bayesian DSGE Approach. Working Paper Series, available at http://www.cbo.gov/ftpdocs/114xx/doc11430/04-2010-Working PaperCrowding out.pdf.

[53] UNCTAD (2016). Economic Development in Africa Report: Debt dynamics and development finance in Africa. United Nations Conference on Trade and Development, New York and Geneva: United Nations.

[54] United Nations Economic Commission for Africa (2019). Economic Report on Africa: Fiscal policy for financing sustainable development in Africa.

[55] Vergara, R. (2004). Taxation and Private Investment Evidence for Chile. Applied Economics, 42, 717-725. 